\title{
Private Medical Institutions Gain over Municipal Ones in the Competition for Customers
}

\author{
S.G. Demchenko \\ Doctor of Economics, Professor, Institute of Economics, Management and Law (Kazan) \\ Email: demchenko@ieml.ru \\ A.L. Faizkhanova \\ Senior teacher of Marketing and Economics Department, Naberezhnye Chelny branch of \\ Institute of Economics, Management and Law (Kazan) \\ Email: afayzhanova@chl.ieml.ru
}

\author{
A.M. Fathiev \\ PhD in Economics, associate professor , Kazan Federal University
}

\section{Doi:10.5901/mjss.2014.v5n18p263}

\section{Abstract}

Objective: to detect factors employed by medical preventive institutions in the market of medical services to achieve competitive advantages. Methods: assessment of opinions of leading scientists on the problem under study; field marketing research based on questionnaire survey and selective personal interview. Results: found that $68 \%$ respondents are not satisfied with provision of medical services by municipal healthcare institutions for certain reasons. Most discontent is caused by waiting turn in a doctor's office for more than an hour, absence of specialized doctors, quality of service, indifferent attitude of doctors to patient, and other reasons. Academic novelty: most attractive aspects of fee-based medical centers have been defined, among which respondents named no lines, presence of specialized doctors, quality services. Practical relevance: achievements of fee-based medical institutions attracting the attention of clients due to higher quality service provide the basis for sharing experience by municipal medical institutions.

Keywords: fee-based medical services, competitive advantages, competition, competitiveness, consumer satisfaction, service attractiveness.

\section{Introduction}

The market of medical services in Russia starting with 1992 together with traditionally existing public and municipal institutions was broadened due to the emergence of private medical preventive institutions, which inevitably led to competition in this industry.

Provision of fee-based medical services is regulated by the Constitution of Russian Federation, Civil Code of Russian Federation, law «On foundations of health protection of citizens in Russian Federation». In art. 7 of the Constitution of Russian Federation health protection comes among the tasks of the social state, also, it recognizes protection (securing) of two basic rights by the state - the right to a decent life (characterized by the minimal range of free amenities for the person, which is provided by the program of state guarantees of provision of free medical assistance for citizens of Russian Federation), and the right to free development (opportunity to access supplementary fee-based amenities).

At present, the area of fee-based medical service where medical services act as goods is actively expanding. Annual growth rate of supply in the market of fee-based medical services makes on average 10-12\%.

Competition in the market of medical services of Russia causes outflow of consumers from public medical institutions in favor of private ones. This is first of all accounted for by dissatisfaction of the population with provision of free medical assistance. The second reason is population income growth, advance in living standards of people, which leads to emergence of consumers willing to pay for quality medical services. The third reason is increase in employment, reducing spare time of people today and their unwillingness to waste time waiting on the line.

The above-mentioned facilitates development of the market of private medical care and enhances the interest to 
studying problems of competitive advantages.

The notion of «competitive advantage» evolved in historical retrospective. One of the first most fundamental researches on this issue was the work of A. Smith. In his work «An Inquiry into the Nature and Causes of the Wealth of Nations», he put forth the theory of «absolute advantages» in solving issues of foreign trade. Absolute advantages, in the opinion of A. Smith, emerge with those countries which secure minimal expenses to manufacture certain goods [1]. The theory of advantages was further developed in the works of D. Ricardo who introduced the notion of «comparative costs» [2]. In his opinion, every country should mostly produce and export goods with relatively less production costs.

Transferring the views of the classics of economic theory to the economic processes of modern realities, we will note that their teachings leaned only on the one side - on the production costs. In addition, the area of their research touched upon competitive advantages in foreign trade with other countries. Our research deals with intra-industry competition in the framework of local markets.

The concept of advantages based on low costs put forth by the classics is still relevant for homogeneous groups of goods displaying the same properties. In today's competitive rivalry, this competition, in M. Porter's apt phrase, was named «advantage in costs». In addition, he considers advantage in costs not as the only factor of success and together with that pays a lot of attention to competitive advantages based on differentiation of goods [3].

A renowned specialist in the area of management and strategic marketing J.J. Lambin also pays attention to the importance of costs naming them «Leadership strategy at the expense of cost savings», but he does not view them as the only prerequisite for competitive advantages [4]. In the opinion of J.J. Lambin whose opinion we fully share, sustainable competitive advantage is achieved by companies conducting constant and systematic analysis of market demands, offering effective goods for the market which are intended for target groups of buyers and possess special features differentiating them from goods-competitors [5]. He defines competitive advantages as «characteristics, features of a product or a brand which create certain dominance of the company over their direct competitors. The mentioned dominance is relative, defined compared to the competitor taking the best position in the market or in the market segment» [4].

In today's economy, search for competitive advantages for the main part stepped out of the area of costs into the area of differentiation of goods and services. At present, the critical factor appears to be not so much издержки, but the uniqueness of selling proposition, exclusiveness and quality of goods. This opinion is shared by many contemporary authors $[6,7,8]$.

Competitive advantages ensure «competitive selection» for the strongest market participants, the opportunity to be distinguished among others and take sustainable positions. The category of «competitive advantage» is implicate with the category of «competitiveness». Both categories reflect leadership of the enterprise and its product in the market. From the standpoint of positive assessment, the mentioned categories are of the same vector: if something is competitive, it consequently possesses competitive advantages; if it possesses competitive advantages, it consequently is competitive. The more competitive advantages the organization has, the higher its competitiveness, rate of survival, effectiveness and viability. In essence, competitive advantage is combination of features and characteristics which give the organization dominance over competitors.

The key issue in the research is the answer to the question: which factors determine competitive advantages in terms of the specific product in the specific market?

We find the answer to the set questions, for example, in the work of G.D. Antonov. He reasonably notes that «competitive advantages represent a system possessing some exclusive value which gives dominance over competitors in economic, technical and organizational areas of activity, the opportunity to more effectively manage the resources they have». G.D. Antonov joins the whole combination of factors determining competitive advantages, into the following groups: economic, structural, scientific-technical and technological, information, spatial, non-material (reputation assets: company name, its trademarks, relationships with consumers, suppliers, the state and society.), non-legal, infrastructural» $[6$, p. 40].

We especially like the position of the above-mentioned author who among non-material factors of competitive advantages includes «reputation assets: company name, its trademarks, relationships with consumers, suppliers, the state and society». This circle of factors belongs directly to the area of marketing research, as well as the "existence of databank of the market, sellers, buyers, competitors». The analysis of G.D. Antonov's position convinces us that the above-mentioned author emphasizes factors ensuring competitive advantages of a certain enterprise at large. At the same time, he does not reveal factors influencing the contentedness of consumers with the offered goods and services.

The more competitive advantages difficult to copy by competitors the company has, the stronger the position of the company in the market is. Market environment is constantly developing, that is why, being influenced by external factors, competitive advantages of the company can lose their relevance or disappear altogether. Any competitive advantage the 
company possesses at present, will ultimately be eliminated by actions of a competent rival possessing sufficient resources. To successfully sustain the competitive advantage, the company must be way ahead of the rivals, taking one strategic attack after another.

O. Malygina offers to view competitive advantages in three areas: factors of temporary competitive advantage, factors of long-term competitive advantage, competence competitive advantages [7]. We believe it is not exactly correct to divide competitive advantages the way $\mathrm{O}$. Malygina did, into those three groups. While the first two groups deal with the temporal aspect, the third classification group, unlike them, is not time bound and can belong both to short-term and long-term perspective.

Long-term competitive advantages are manageable, hard to copy by competitors parameters of internal environment of an organization, development of which provides such characteristics as consumer value, uniqueness, novelty of the product.

We agree with the position of F.N. Vinokurov who considers that the matter of competitive advantages depends on the industry where the company functions. Companies working in high-technology industries will link their competitive advantages «to technical superiority, product or technological innovations, for companies working in the mass market, this may be brand awareness, low costs, location, etc.» [9].

The problem of competitive advantages being applied to medical services has not been sufficiently covered in the literature of the subject. The most significant contribution to this issue was made by M. Porter. He writes, «...acute lack of comparative information and absence of objective criteria of the activity results assessment in the system of medical services create for hospitals and doctors incentives for competition based on what is on the surface: comfortable surroundings, up-to-date equipment, wide range of services, engaging manners of doctors, and even... high price» [3, $\mathrm{p}$. 517].

In the market of medical services in Russia, there emerged a competitive environment determined by alternative forms of ownership. Together with municipal medical institutions, the competitive environment is made by private medical institutions striving by way of competitive advantages to attract clients treated previously by only municipal institutions. This enhances relevance of studying competitive advantages applied to medical services.

Medical industry has its specific factors of competitive advantages, spoken about in the work of A. Akopyan, V. Murashov, R. Bochkarev. In their opinion, competitiveness of a medical service is built not upon «hard» (i.e. measured in absolute units), but upon «soft» (measured in relative units) parameters [10, p. 98]. Those parameters can be acquired by only survey methods.

Since the main person for whose sake competitive advantages are created is the buyer, we detected factors by which the buyer is guided while choosing a medical preventive institution.

\section{Results of Research}

To detect the main factors making a medical service attractive for consumers, we arranged the marketing research by the method of personal interview in March 2013. 420 people aged 20 to 65 were surveyed, of them 306 women (73\%) and 114 men (27\%). As for distribution of respondents according to social background, they were mainly office staff $-52 \%$, workers $-17 \%$, then management $-12 \%$, pensioners $-9 \%$, other categories made the rest $10 \%$. The surveyed were asked an open question which allowed to define factors influencing the consumer's choice of a health care provider, implying that the consumer gives preference to the deliverer who offers a service equipped with competitive advantages attractive for the buyer.

As a result, we defined a list of factors meaningful for a consumer while choosing a medical institution (pic. 1).

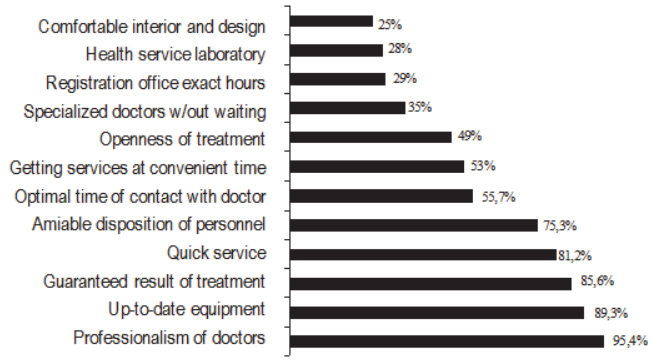

Pic. 1. Factors meaningful for a consumer while choosing a medical institution 
We divided the detected factors influencing consumer preferences, into three groups according to the level of their significance.

The first group includes the most significant or critical advantages:

1. Professionalism of doctors;

2. Up-to-date equipment;

3. Guaranteed result of treatment;

4. Quick service;

5. Amiable disposition of personnel.

Into the second group respondents included advantages which are desirable:

6. Optimal time of contact with doctor;

7. Getting services at convenient time;

8. Openness of treatment;

9. Appointment with specialized doctors without waiting.

Into the third group the surveyed included the least significant advantages:

10. Registration office exact hours;

11. Healthcare laboratories;

12. Comfortable interior and design.

The analysis of the notion of «competitive advantage» reflected in the works of many authors $[3,4,5,7,8,10]$ and results of field research aimed at empirical detection of factors significant for consumers, allowed us to state the essence of competitive advantages of medical services. By competitive advantages we understand combination of unique characteristics and features of medical services satisfying demands of consumers, presence or absence of which determines success of medical institutions in the market. The unique characteristics of competitive advantages reflecting the specifics of medical services include, for instance, opportunity to get professional assistance of specialized doctors, advanced technologies and up-to-date equipment, guarantee of long-term effect from the provided service, being served at the needed time without waiting on the line.

The marketing research allowed us to define the degree of satisfaction of patients with the quality of medical services, and consequently competitive advantages by combination of characteristics and features of medical services [11].

We conducted the research based on materials of Naberezhnye Chelny, Republic of Tatarstan, yet its main regularities and conclusions are of trans-territorial character and will be helpful for comparative analysis with other cities.

All the surveyed at least once in a lifetime applied for fee-based medical assistance, and $84 \%$ got it both in municipal and in private medical institutions, $16 \%$ - only in fee-based ones. Further, almost half of the surveyed (46\%) applied for fee-based services forcedly (there was no opportunity to get the necessary assistance for free), $37 \%$ did that voluntarily, $17 \%$ - forced by circumstances (urgent examination was necessary). Attitude of most respondents to feebased medicine is negative (57\%), positive $-27 \%$, indifferent $-16 \%$. Besides, most respondents are convinced that free high-technology assistance is unavailable in the city - $86 \%$ think so (respondents note only fee-based opportunity), and only $14 \%$ consider it accessible.

The second stage of the research was detection of the degree of contentedness by the services of private medical centers. Most respondents apply for medical services less than once a year $-34 \%$, once a year $-26 \%$, once half a year - $20 \%$, once in three months $-10 \%$, other variants $10 \%$. Most frequently they go to fee-based medical centers for diagnostic services $-55 \%$, for specialized doctors services $-28 \%$, undergo medical tests in fee-based centers $-10 \%$, for other services $-7 \%$.

While choosing fee-based medical centers, respondents consider most attractive: no lines (71\%), presence of specialized doctors (55\%), quality services (40\%), a small amount of them indicate other factors, such as: appointment at weekends and days off, consideration of personnel, comfortable interior, etc.

$14 \%$ are fully satisfied with the services of private medical centers, more satisfied than not $-76 \%$, more dissatisfied than satisfied - 9\%, not satisfied only $1 \%$. Meaningful factors while choosing a fee-based medical center are, in decreasing order: professionalism and competence of doctors; results of treatment; quick service; up-to-date equipment; service culture; amiability, attention and the doctor's concern with the patient's problems; cleanliness; «quality-to-price» ratio; sufficient information about the treatment process; amiability of nursing staff; comfortable interior.

Attitude of doctors to patients in private medical centers is for the main part, in the opinion of respondents, diligent $-70 \%$ ), very diligent $-26 \%$, indifferent $-4 \%$. Attitude of nursing staff is estimated, correspondingly, as follows: diligent $66 \%$, very diligent $-25 \%$, indifferent $-9 \%$. Attitude of front desk personnel is estimated mainly as diligent $-61 \%$, very diligent $-29 \%$, indifferent $-10 \%$. 
During the conducted research, we detected cases of negative attitude of patients to municipal sector of medical services compared to private ones. The main complaint sounded by patients is long lines to visit the doctor. The forced communication of the healthy and sick on lines leads to recontamination, discontent of patients, irritability, which, in turn, influences the doctors' work. Some respondents noted cases of absence of specialized doctors. Personnel problems naturally affect the accessibility and quality of provision of services. Several respondents noted cases of bureaucracy which, in the opinion of the respondents, is not always justified.

Advantages of private medical centers were found: keeping time of visit (on average 40 minutes for a patient), opportunity of consultation with a specialized doctor which allows for more precise diagnostics, urgent tests and examinations, employment of additional methods of examination, up-to-date equipment and opportunity of acquiring what is lacking, advanced training. Negative points include irregular working hours, yet salary of doctors in private medical centers did not change for the last 5 years, unlike in public ones.

Reasons were detected for which patients give preference to private medical preventive institutions:

- professionalism and competence of doctors (only high qualified specialists with experience are invited to work in private clinics, moreover, they have an opportunity to continually improve their skill attending various seminars and training programs);

- prevalence of positive outcomes of treatment;

- quick service (in fee-based centers conduct pre-appointment for a visit, where each patient is allotted certain time, average of 40 minutes); up-to-date equipment (to raise its competitiveness, private clinics employ the latest technologies), service culture (in practically all private medical centers there exist rules of communication standards with patients where they are viewed as important persons and are treated correspondingly, patients database is worked out which is studied by the doctor prior to the visit),

- cleanliness and comfort (in private clinics, they created comfortable interior in compliance with all sanitaryhygienic standards, and shoe wrappers are distributed free of charge, unlike in municipal polyclinics), sufficient information about the treatment process (doctors explain to the patient the root of his problem speaking over the treatment procedure) and many others. Medical services in fee-based clinics are provided every day, in some of them with no days off, unlike in municipal medical institutions.

\section{Conclusions}

Private medical preventive institutions win the competitive rivalry due to provision of higher quality fee-based medical services and diligent attitude to demands of consumers, and municipal medical preventive institutions lose by these factors. Yet, municipal institutions solve a serious social task providing free medical services for the population. One of the problems of municipal medical institutions is underfunding.

From our point of view, it is necessary to further develop private-public partnerships in the sphere of medical services, to attract resources of private business, initiative, entrepreneurial zeal together with state healthcare institutions.

It is necessary to launch mechanisms of convergence, benchmarking, interpenetration and sharing best practices between municipal and private medical institutions. This will allow in the framework of private-public partnership to improve quality of medical services due to provision of high-technology medical assistance, competitive advantages and marketing focus on meeting the needs of consumers in the best way. As a result of such partnership and competitive rivalry, consumer is a winner.

\section{References}

Smith A. An Inquiry into the Nature and Causes of the Wealth of Nations. - M.: Eksmo, 2007. - 960 p.

Ricardo D. The Principles of Political Economy and Taxation. Selected works. - M.: Eksmo, 2007. - 960 p.

Porter M. Competitive Advantage: Creating and Sustaining Superior Performance: tr. from Eng. - M.: Alpina Biznes Buks, 2008. - 714 p.

Lambin J.-J., Chumpitaz R., Schuiling I. Market-Driven Management. - SPb: Piter, 2011. - 720 p.

Lambin J.-J. Strategic Marketing. - SPb.: Nauka, 2007. - 201 p.

Antonov G.D., Ivanova G.D., Tumin V.M. Management of organization competitiveness: textbook. - M: Infra-M, 2012. - 300 p.

Malygina O. Key competence of company as competitive advantage // Problems of theory and practice of management: international journal. - 2008. - № 10. - P. 116-126.

Ilyina E.I. Management of competitiveness of enterprises of tertiary industry and provision of services as component of innovative development // Economic analysis: theory and practice. - 2012. - № 10. - P. 112-119.

Vinokurov F.N. Case of empirical research of customer loyalty for a brand // Moscow University Herald - 2012 . - № 1. - P. 155-161.

Akopyan A., Murashov V., Bochkarev S. Peculiarities of competition in the market of medical services and medical supplies // Marketing 
- 2001. - № 4 - P. 97-98; № 5. - P. 94-101.

Demchenko S.G., Faizkhanova A.L. In competitive rivalry municipal medical institutions lose to private ones // 'Aktualniye problemy ekonomiki i prava' (Actual Problems of Economics and Law). 2013, №3 (27) P. 89-96. 